\title{
Assessment of Heavy Metals in Peppers Sold in Major Markets in Osogbo, Osun State, Southwest, Nigeria
}

\author{
FAROMBI Abolaji Grace, ORISADARE Oluseyi Adewale*, ABIOYE Ismail Olawale, \\ BABATOLA Babatunde Keji \\ Department of Science Laboratory Technology, Faculty of Science, Osun State Polytechnic Iree, Osun State, \\ Nigeria.
}

*Corresponding Author: ORISADARE Oluseyi Adewale, Department of Science Laboratory Technology, Faculty of Science, Osun State Polytechnic Iree, Osun State, Nigeria.

\begin{abstract}
Heavy metal concentrations in four pepper samples sold in major markets in Osogbo, Osun State, Southwestern Nigeria was investigated in this research work. The heavy metals analyzed for include, Cadmium $(\mathrm{Cd})$, Iron ( $\mathrm{Fe}$ ), Lead ( $\mathrm{Pb}$ ), Zinc ( $\mathrm{Zn}$ ), Cobalt ( $\mathrm{Co}$ ) and Chromium (Cr) using Atomic Absorption Spectrophometry method. The results of the analysis revealed that Cadmium ranged from $0.008 \pm 0.0009$ ppm to $0.022 \pm 0.0009$ ppm; $\operatorname{Iron}(0.022 \pm 0.0003$ to $0.100 \pm 0.0008 \mathrm{ppm})$, Lead $(0.002 \pm 0.0001$ to $0.009 \pm 0.0002 \mathrm{ppm})$, Zinc (0.013 \pm 0.0003 to $0.064 \pm 0.0004 \mathrm{ppm}$ ) Cobalt $(0.010 \pm 0.0004$ to $0.036 \pm 0.0003 \mathrm{ppm})$ and Chromium $(0.003 \pm 0.0001$ to $0.034 \pm 0.0008$ ppm) for all the analyzed pepper samples. The heavy metals concentrations in the peppers samples were significantly different at $p<0.05$ level of significance among the selected markets.From the results, the levels of contamination by these heavy metals on the pepper samples were very low when compared to the permissible limits stipulated by FAO/WHO (2012).
\end{abstract}

\section{INTRODUCTION}

Pepper (Capsicum spp) is an important fruit vegetable in the tropics and the world second most important vegetable after tomatoes (Olaniyi and Ojetayo, 2010). Nigeria is the largest producer of pepper in Africa, producing about $50 \%$ of the total African production on approximately 200,000 hectares of farmland annually. Pepper production in Nigeria stood at 695,000 metric tons obtained from an area of 77,000 ha, which gives an average yield of 9,026 metric tons per hectare (FAO, 2008). Pepper is often grown solely or in mixtures with either cereals crops or other vegetables. It is often consumed fresh, dried or processed and along with other fruit vegetables like tomato, onion, among others. It is an important spice crop highly cherished for its pungent flavour. Over the years, pepper has increased in popularity, value and importance, thus standing as an indispensable part of the daily diet of Nigerians (in their millions).

However, significant quantities of heavy metals have been detected in natural food spices such as pepper (Gaya and Ikechukwu, 2016).Whilesome heavy metalssuch as; chromium, iron, manganese, cobalt, zinc andcopper are considered essential at low levels, other metals such as cadmium and lead in their low levels can havetoxic effects in human biochemical reactions (Järup, 2003; Cao et al., 2010). Recently, lead and cadmium were listed by the Agency for Toxic Substances and Disease Registry (ATSDR) as second and seventh priority toxic substances (ASTDR, 2015).The accumulation of theseimportant hazardous metals can breed middle-term orlong-term health effects manifesting as depression, chronic asthma, liver damage, insomnia,kidney damage and neurological disorders (Mandaland Suzuki, 2002; Barakat, 2011).

Heavy metals are referred to as metals having specific density greater than $5 \mathrm{~g} / \mathrm{cm}^{3}$, and are found at different concentrations in the earth's crust. Their deposition in soil occurs at a faster rate, at higher $\mathrm{pH}$ and as well as in the presence of a high proportion of carbonates (Abdalla, 2014). Their accumulation can be found in the surface layer of the soil. The increase in their concentrations in soil increases their absorbance by plants, which in turn may cause havoc to human's life. Over the years, human activities 
via industrial, agricultural, traffic, domestic, mining and other anthropogenic activities have contributed immensely to the high and toxic levels of these metals in the environment (Osakwe and Okolie, 2015). Heavy metals are enormouslyinsistent in the environment; they are non-biodegradable and nonthermodegradable and thus readily accumulate to toxic levels (Ahmed and Bouhadjera, 2010).

Toxicity of heavy metals can damage or reduce mental and central nervous function, worsen energy level and damage to blood composition, lungs, kidney, liver and other essential organs. Long term exposure to heavy metals may lead to slowly progressing physical, muscular and neurological degenerative process in form of Alzheimer disease, Parkinson's disease, muscular dystrophy and multiple sclerosis. Allergies are not uncommon and repeated long term contract with some metal (or their compounds) may cause cancer (Michael, 2010). The presence of heavy metals in food substance constitutes serious health hazards, developing in their relative level (Luke, 1997). Hence, this present study aims at investigating the concentrations of heavy metals in peppers sold in major markets in Osogbo, Osun State, and their significance in relation to the health of people consuming these peppers.

\section{MAterials ANd Methods}

\subsection{Materials}

Pepper samples were bought from six markets in Osogbo, five of which are located along high traffic areas viz: Ota-Efun market, Oja-Oba market, Igbona market, Orisunbare market and Oluode and the sixth market: Shasha market which is located in a traffic free area, with the aim of analyzing heavy metals concentrations present in the peppers sold in these markets. The study area lies within latitude $07^{\circ} 45^{\prime} 57^{\prime \prime} \mathrm{N}$ and $07^{\circ} 49^{\prime} 17^{\prime \prime} \mathrm{N}$ and longitude $04^{\circ} 32^{\prime} 14^{\prime \prime} \mathrm{E}$ and $04^{\circ} 35^{\prime} 47^{\prime \prime} \mathrm{E}$. The study area has two local government areas (LGAs) namely: Olorunda LGA and Osogbo LGA. The six markets were selected such that three markets were selected from each LGA. While Igbona, Orisunbare and Ota-Efun markets were selected from Olorunda LGA, Oluode, Oja-Oba and Shasha markets were selected from Osogbo LGA. Figure 1 shows the map of the study area showing the sample locations. The area falls within the lowland tropical rain forest vegetation most of which had since given way to secondary forest and derived savannah. The secondary vegetation is due to fuel wood production, quarrying and traditional farming practices and other developmental projects like road constructions (Tijani and Onodera, 2009). The climate is tropical hinterland type with mean annual temperature of about $27^{\circ} \mathrm{C}$. Two main climatic seasons are found in this area, which include: a dry season which starts from November to early March and a wet season between late March and early November with mean annual rainfall of 1000-1250mm. The drainage pattern is moderately dense and dendritic, dominated by Osun River and its tributaries, which are largely controlled by the structural trends within the Basement Complex terrain(Tijani and Onodera, 2009).

\subsection{Methods}

\subsubsection{Sample Collection and Preparation}

A total of seventy-two (72) samples of pepperswere used in this study. The peppers samples which include; tomato, tatashe (Bell pepper), bawa (red pepper) and rodo (Chili pepper) were purchased from the six (6) markets. The peppers were purchased from three sales points per market. The samples were collected in nylon bags and labeled properly. In order to ensure that heavy metals determined are exclusively those taken up by the plants from the soil, each sample was properly washed with tap water and then with deionized water. The samples were then dried in air, followed by oven drying at $80^{\circ} \mathrm{C}$ until constant weight was achieved. The dry samples were ground to fine particle using laboratory mortar and pestle, stored in airtight nylons and properly labeled.The pepper samples were then transferred to the laboratory at the Centre for Energy and Research Development (CERD), Obafemi Awolowo University, Ile-Ife, Osun State, Nigeria for analysis of some heavy metals $(\mathrm{Cd}, \mathrm{Fe}, \mathrm{Pb}, \mathrm{Zn}$, Co, and $\mathrm{Cr}$ ). 


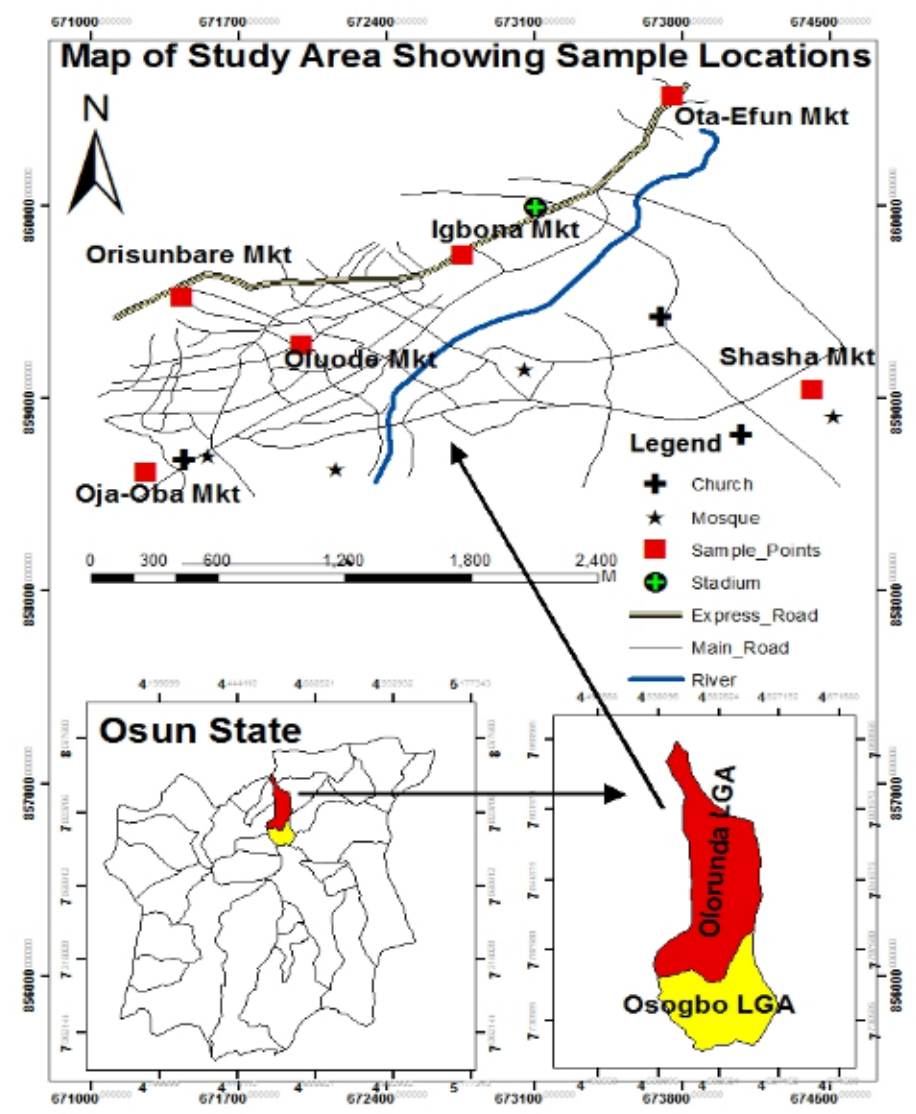

Figure1. Shows the map of the study area showing the sample locations

\subsubsection{Sample Digestion}

The determination of heavy metal concentrations was carried out using wet digestion method as described by Jone and Case (1990) as adopted by Makanjuola and Osinfade(2016). O.5g of each pepper sample was placed in $100 \mathrm{ml}$ beaker and $3.5 \mathrm{ml}$ of $30 \% \mathrm{H}_{2} \mathrm{O}_{2}, 3 \mathrm{ml} \mathrm{H}_{2} \mathrm{SO}_{4}, 0.5 \mathrm{ml} \mathrm{HNO}_{3}$ and $1 \mathrm{ml} \mathrm{HCLO}_{3}$ were added. The content in each beaker was first heated to $100^{\circ} \mathrm{C}$, gradually increased to $250^{\circ} \mathrm{C}$, and was then left at this temperature for 30 minutes. Each beaker and its content were then allowed to cool and an additional $1 \mathrm{ml}$ of $30 \% \mathrm{H}_{2} \mathrm{O}_{2}$ was added to the digestion mixture and reheated. The digestion process was repeated until a clear solution was obtained in each case. The clear solution was transferred to $50 \mathrm{ml}$ volumetric flask, made up to mark with distilled water. Blank solution was also prepared. Standard solution for each element under investigation was prepared and used for calibration. Measurement for each heavy metal was carried out using Atomic Absorption Spectrophotometer with double beam and deuterium background correction (Buck Atomic Absorption Spectrophotometer model 210/211 VGP).

\subsubsection{Heavy Metal Determination}

The filtrate resulting from wet digestion was subsequently analyzed for $\mathrm{Cd}, \mathrm{Fe}, \mathrm{Pb}, \mathrm{Zn}, \mathrm{Co}$, and $\mathrm{Cr}$ using Buck flame atomic absorption spectrophotometer (AAS). The AAS was fueled by acetylene. Standards were analyzed accordingly but without the pepper. The actual concentrations were extrapolated from calibration curves. Analytical concentrations of the analyzed pepper were measured in parts per million (ppm). Each analysis was repeated twice and standard deviations from the mean values were calculated (Gaya and Ikechukwu, 2016).

\subsection{Statistical Analysis}

The results obtained from the laboratory analysis were generally expressed as mean \pm standard deviation with minimum and maximum for each heavy metal. The laboratory results were subjected to the inferential statistical analysis using IBM SPSS Statistics 20.0 in order to ascertain the levels of significant differences at $\mathrm{p} \leq 0.05$ of the heavy metals from different markets and in different peppers. The laboratory results were subjected to statistical Analysis of Variance (ANOVA)to investigate the effects of location variation on the heavy metals in the selected peppers and the Post hoc test of ANOVA 
using Duncan Multiple Range Test (DMRT) to separate the means. Also, the laboratory results were subjected to correlation analysis to investigate the relationships among the considered heavy metals.

\section{RESULTS AND DISCUSSION}

\subsection{Results}

The mean concentrations of heavy metals in peppers sold in Osogbo markets are presented in Table 1. The results are presented according to the peppers groups: tomato, tatashe (Bell pepper), bawa (Red pepper) and rodo (Chili pepper), and the locations where the peppers were bought in Osogbo. The result of post hoc test of ANOVA using Duncan Multiple Range Test (DMRT) and the result of correlation analysis using SPSS were shown in Tables 2 and 3.

Table1. Mean concentrations (ppm) of heavy metals in peppers

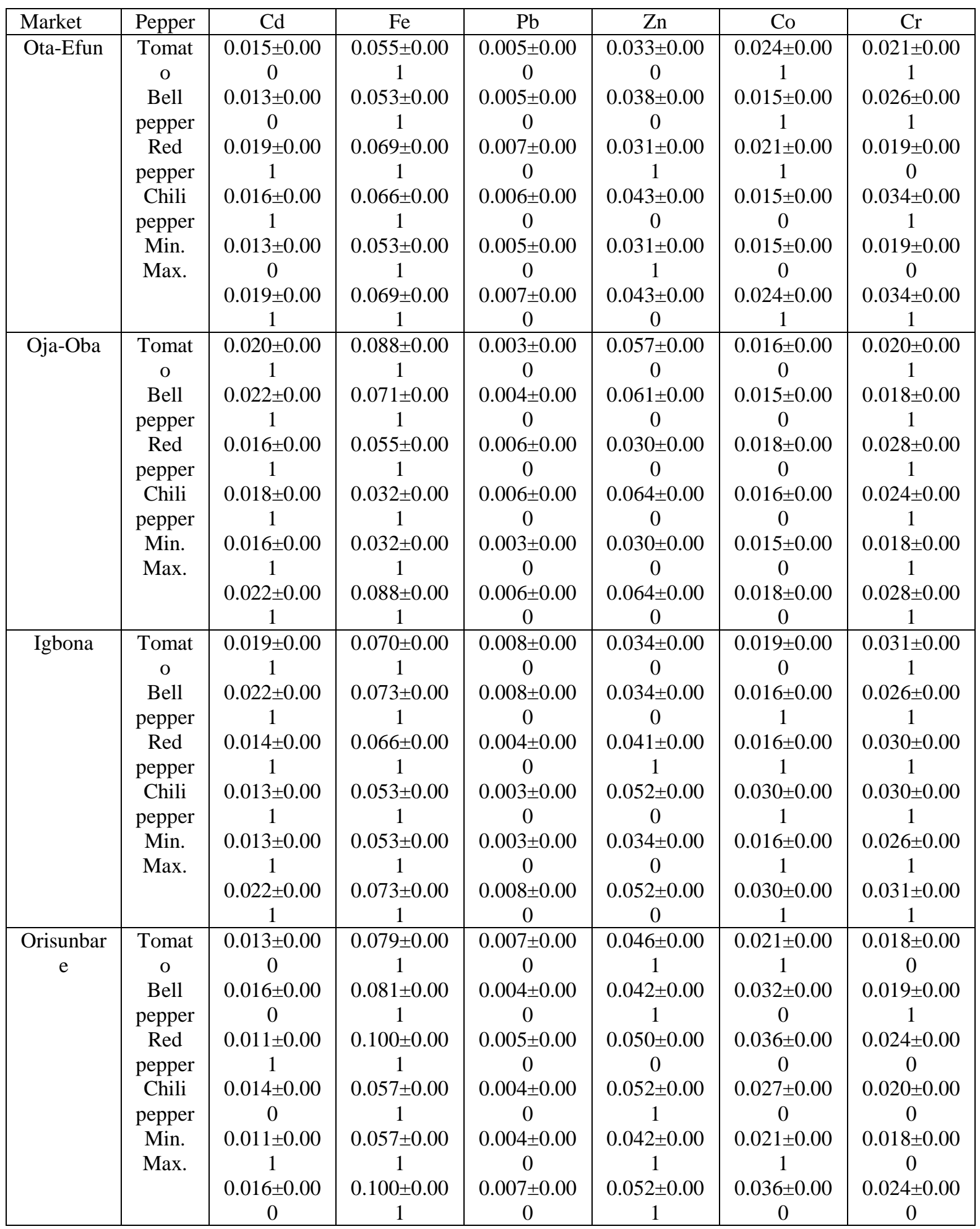




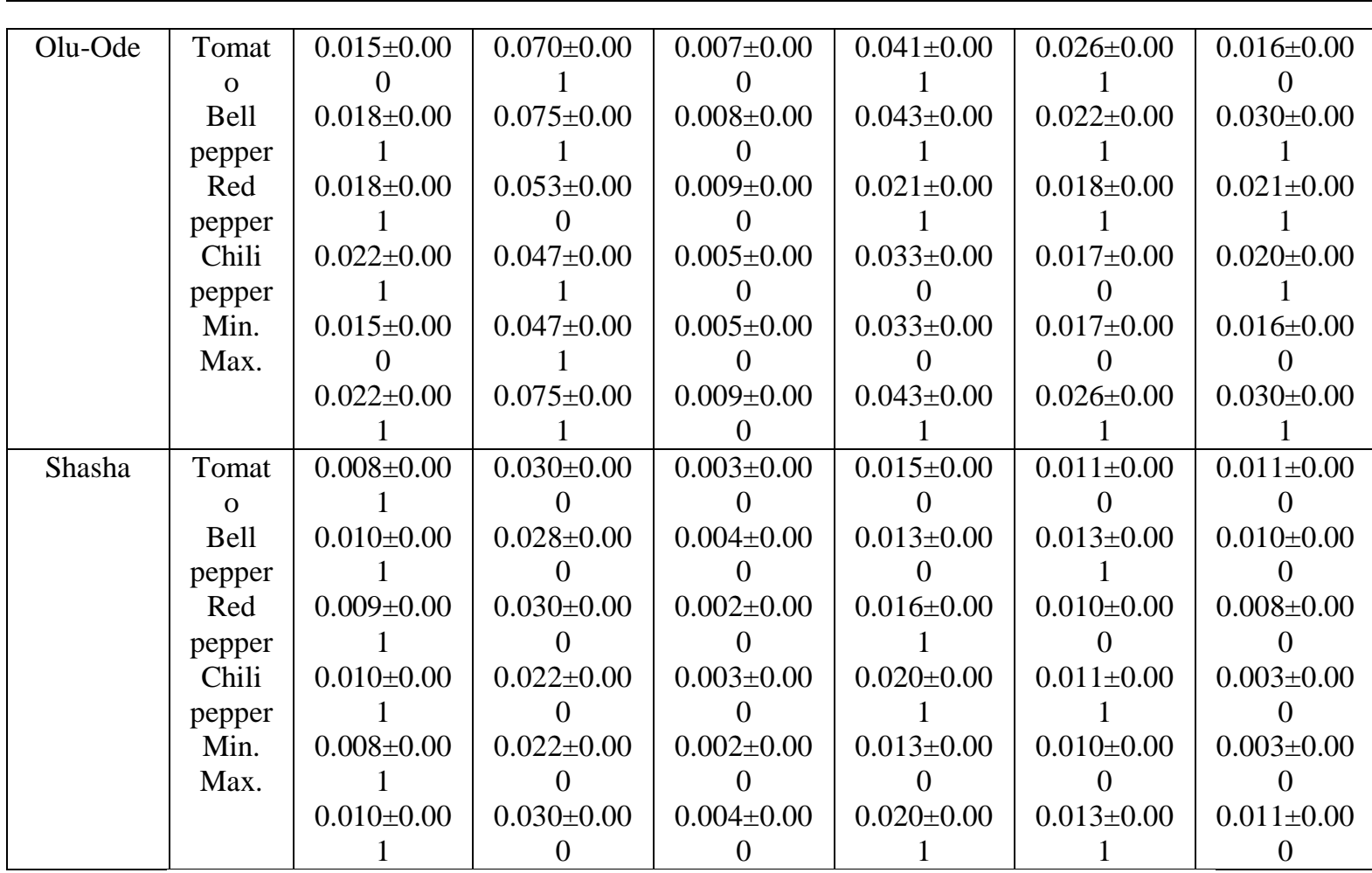
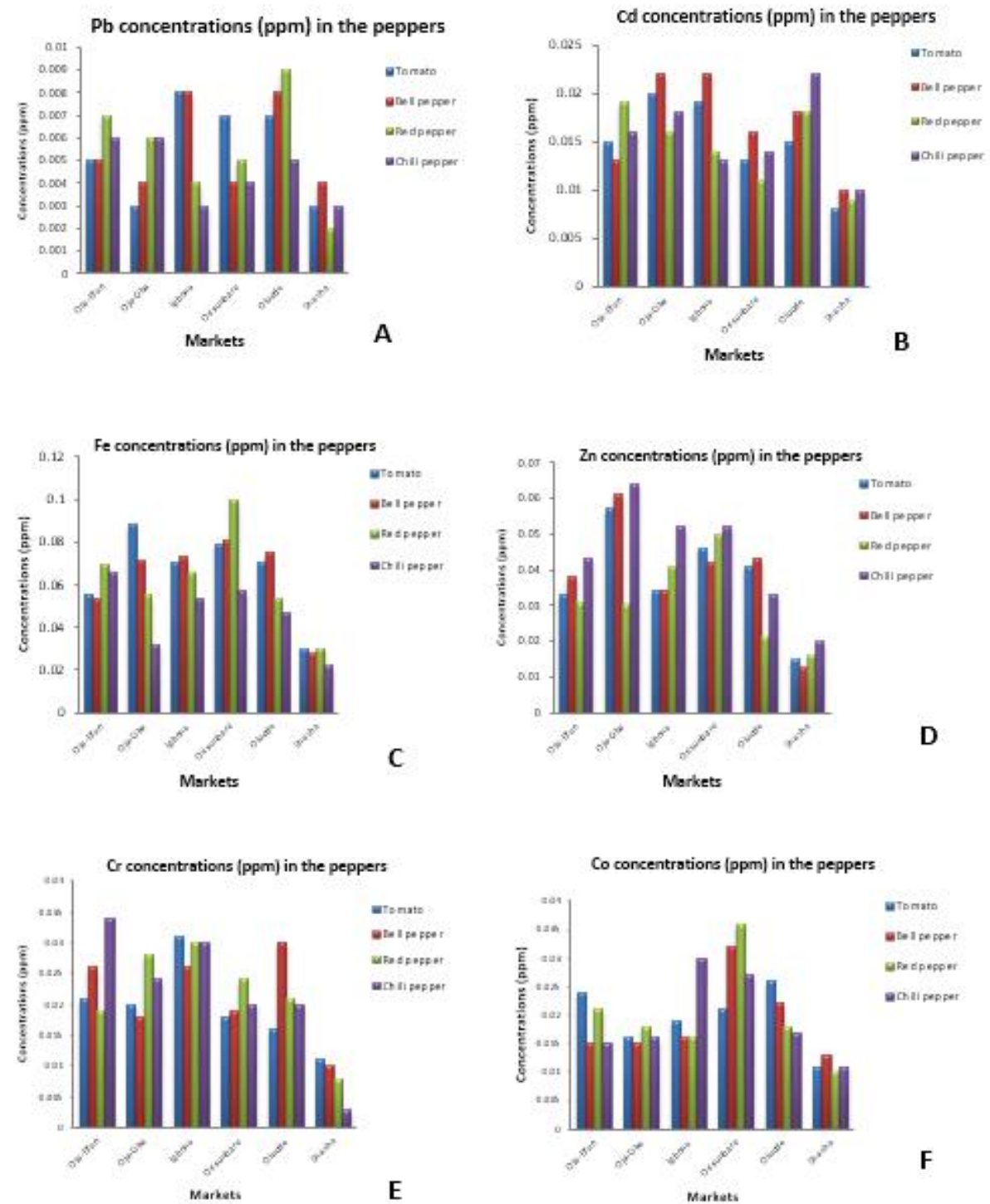

Figure2. Concentrations (ppm) of heavy metals in the peppers sold in Osogbo markets 
Table2. Effects of location variation on the heavy metals in the pepper samples

\begin{tabular}{|c|c|c|c|c|c|c|}
\hline \multirow{2}{*}{ Markets } & \multicolumn{6}{|c|}{ Heavy metals concentrations (ppm) } \\
\cline { 2 - 7 } & $\mathbf{C d}$ & $\mathbf{F e}$ & $\mathbf{P b}$ & $\mathbf{Z n}$ & $\mathbf{C o}$ & $\mathbf{C r}$ \\
\hline $\begin{array}{c}\text { Ota-Efun } \\
(\mathrm{n}=12)\end{array}$ & $0.01575^{\mathrm{c}}$ & $0.06075^{\mathrm{b}}$ & $0.00575^{\mathrm{b}}$ & $0.03625^{\mathrm{b}}$ & $0.01875^{\mathrm{bc}}$ & $0.02500^{\mathrm{c}}$ \\
\hline $\begin{array}{c}\text { Oja-Oba } \\
(\mathrm{n}=12)\end{array}$ & $0.01900^{\mathrm{d}}$ & $0.06150^{\mathrm{b}}$ & $0.00475^{\mathrm{b}}$ & $0.05300^{\mathrm{c}}$ & $0.01625^{\mathrm{b}}$ & $0.02250^{\mathrm{bc}}$ \\
\hline $\begin{array}{c}\text { Igbona } \\
(\mathrm{n}=12)\end{array}$ & $0.01700^{\mathrm{cd}}$ & $0.06550^{\mathrm{b}}$ & $0.00575^{\mathrm{b}}$ & $0.04025^{\mathrm{b}}$ & $0.02025^{\mathrm{c}}$ & $0.02925^{\mathrm{d}}$ \\
\hline $\begin{array}{c}\text { Orisunbare } \\
(\mathrm{n}=12)\end{array}$ & $0.01350^{\mathrm{b}}$ & $0.07925^{\mathrm{c}}$ & $0.00500^{\mathrm{b}}$ & $0.04750^{\mathrm{c}}$ & $0.02900^{\mathrm{d}}$ & $0.02025^{\mathrm{b}}$ \\
\hline $\begin{array}{c}\text { Oluode } \\
(\mathrm{n}=12)\end{array}$ & $0.01825^{\mathrm{d}}$ & $0.06125^{\mathrm{b}}$ & $0.00725^{\mathrm{c}}$ & $0.03450^{\mathrm{b}}$ & $0.02075^{\mathrm{c}}$ & $0.02175^{\mathrm{bc}}$ \\
\hline $\begin{array}{c}\text { Shasha } \\
(\mathrm{n}=12)\end{array}$ & $0.00925^{\mathrm{a}}$ & $0.02750^{\mathrm{a}}$ & $0.00300^{\mathrm{a}}$ & $0.01600^{\mathrm{a}}$ & $0.01125^{\mathrm{a}}$ & $0.00800^{\mathrm{a}}$ \\
\hline
\end{tabular}

Mean values followed by the same alphabet in the same column are not significantly different at $p<0.05$ level of significance according to Duncan Multiple Range Test

Table3.3. Correlation analysis of heavy metals in the peppers

\begin{tabular}{|c|c|c|c|c|c|c|}
\hline & $\mathrm{Cd}$ & $\mathrm{Fe}$ & $\mathrm{Pb}$ & $\mathrm{Zn}$ & $\mathrm{Co}$ & $\mathrm{Cr}$ \\
\hline $\mathrm{Cd}$ & 1 & & & & & \\
\hline $\mathrm{Fe}$ & $0.430^{* *}$ & 1 & & & & \\
\hline $\mathrm{Pb}$ & $0.516^{* * *}$ & $0.354^{* *}$ & 1 & & & \\
\hline $\mathrm{Zn}$ & $0.435^{* *}$ & $0.557^{* *}$ & 0.027 & 1 & & \\
\hline $\mathrm{Co}$ & 0.031 & $0.614^{* *}$ & 0.141 & $0.448^{* *}$ & 1 & 1 \\
\hline $\mathrm{Cr}$ & $0.455^{* *}$ & $0.509^{* *}$ & $0.464^{* *}$ & $0.487^{* *}$ & $0.320^{* *}$ & \\
\hline
\end{tabular}

${ }^{* *}$ Correlation is significant at the 0.01 level (2-tailed).

\subsection{Discussion}

The mean concentrations of some heavy metals (ppm) in the sold peppers in selected markets in Osogbo, Osun State, Southwest, Nigeria, were shown in Table 1. The four peppers considered in this study were analyzed for six heavy metals viz: Cadmium, Iron, Lead, Zinc, Cobalt and Chromium. As shown in Table 1, Iron has the highest mean concentrations $(0.100 \pm 0.001 \mathrm{ppm})$ recorded for Red pepper obtained from Orisunbare market, Chromium and Lead have the least concentrations of $(0.003 \pm 0.000 \mathrm{ppm})$ and $(0.002 \pm 0.000 \mathrm{ppm})$ as obtained in Chili pepper and Red pepper of Shasha market respectively. The average abundance of heavy metals in the pepper samples investigated was of the order $\mathrm{Fe}>\mathrm{Zn}>\mathrm{Co}>$ $\mathrm{Cr}>\mathrm{Cd}>\mathrm{Pb}$. In the result, $\mathrm{Pb}$ had the lowest concentration, while $\mathrm{Fe}$ had the highest concentration for all the peppers analyzed. The highest mean concentration of $\mathrm{Pb}$ was found in red pepper $(0.009 \pm 0.000$ $\mathrm{ppm}$ ) obtained from Olu-Ode market. This corroborates the concentration of $\mathrm{Pb}$ in peppers as reported by Makanjuola and Osinfade, (2016). In plant growth and development, $\mathrm{Pb}$ has been reported to have harmful impact on various metabolic processes to include photosynthesis, transpiration, genetic synthesis and mitotic activity (Kimani et al., 2011 and Wierzbicka M, 1999). In humans, effects of $\mathrm{Pb}$ accumulation include hematological effects, neurological and behavioral effects, renal effects, cardiovascular effects, effects on the reproductive system, effects on bone and on theimmune system in laboratory animals, (International Programme on Chemical Safety (IPCS); 1992). However, when the values of $\mathrm{Pb}$ was compared with the maximum permissible limit of $0.3 \mathrm{ppm}$ set by FAO/WHO (2012) for leafy vegetables and fruiting vegetables, the result showed that $\mathrm{Pb}$ values were below the FAO/WHO limits. Pepper samples from Shasha market revealed low concentrations of $\mathrm{Cd}$ compared to other selected markets as shown in Figure 2 A. This can be connected to the vehicular exhaust from the heavy traffic and other gaseous air pollutant along these markets (Makanjuola and Osinfade, 2016). The highest concentration of $\mathrm{Cd}$ was found in Bell and Chilli peppers $(0.022 \pm 0.001 \mathrm{ppm})$ obtained from Igbona and Olu-Ode markets respectively. The accumulation of cadmium in the kidney leads to renal dysfunction, chronic obstructive airway disease is associated with long-term high-level occupational exposure by inhalation, (IPCS, 1992 and Kimani et al., 2011). When compared with the maximum permissible limit of $0.05 \mathrm{ppm}$ set by FAO/WHO (2012) for leafy vegetables and fruiting vegetables, the result showed that cadmium values were below the FAO/WHO limits. 
Thehighest concentration of $\mathrm{Zn}(0.064 \pm 0.000 \mathrm{ppm})$ was found in chilli pepper obtained from Oja-Oba market and peppers from Shasha market had the lowest concentration of $\mathrm{Zn}$. In human, $\mathrm{Zn}$ is important for growth and development (Cloak, et al., 2005 and Darko et al., 2014). Whereas, high levels of zinc cause acute effects such as vomiting and gastrointestinal irritation (nausea, cramps, diarrhea), (International Programme on Chemical Safety (IPCS); 1992). When the values of $\mathrm{Zn}$ in this study was compared with the maximum permissible limit of 48 ppm set by FAO/WHO (2012) for leafy vegetables and fruiting vegetables, the result showed that $\mathrm{Zn}$ values are below the FAO/WHO limits. The mean concentrations of $\mathrm{Fe}$ for all the peppers considered from the studied markets are generally low for Shasha market compared with other markets as shown in Figure 1B. Excess iron intake may result in siderosis (deposition of iron in tissue) in liver, pancreas, adrenals, thyroid, pituitary and heart depending on the chemical form, (International Programme on Chemical Safety (IPCS); 1992). The result showed that $\mathrm{Fe}$ values were below the FAO/WHO limits of $48 \mathrm{ppm}$. The highest mean concentrations of Co is found in red pepper $(0.036 \pm 0.000 \mathrm{ppm})$ obtained from Orisunbare market. The result showed that Co values are below the FAO/WHO (2012) limits in plants of $3.5 \mathrm{ppm}$ and therefore poses no health risk to consumers of these peppers. Cr has the highest mean value of $(0.034 \pm 0.001 \mathrm{ppm})$ in chilli pepper obtained from Ota-Efun market. When the values of $\mathrm{Cr}$ was compared with the maximum permissible limit of $1.0 \mathrm{ppm}$ set by FAO/WHO (2012) for leafy vegetables and fruiting vegetables, the result showed that $\mathrm{Cr}$ values were below the $\mathrm{FAO} / \mathrm{WHO}$ limits.

The result of the post hoc test of ANOVA of the laboratory analysis carried out on the pepper samples from the major markets in Osogbo as shown in Table 2. There was a statistically significant difference in the concentrations of the heavy metals investigated at $p<0.05$ level of significant. The result of analysis of correlation in SPSS of the six heavy metals investigated in this study was shown in Table 3. The result revealed that there was a positive significant correlations among the heavy metals in all the peppers at $\mathrm{p}<0.01$ significant level. Cd was positively correlated with $\mathrm{Fe}, \mathrm{Pb}, \mathrm{Zn}$ and $\mathrm{Cr}$ but showed no relationship with $\mathrm{Co}$. Fe showed significant positive correlation with $\mathrm{Pb}, \mathrm{Zn}, \mathrm{Co}$ and $\mathrm{Cr}$. $\mathrm{Pb}$ showed non-significant correlation with $\mathrm{Zn}$ and $\mathrm{Co}$ but was positively correlated with $\mathrm{Cr}$. $\mathrm{Zn}$ was positively correlated with $\mathrm{Co}$ and $\mathrm{Cr}$, and there was also a positive significant correlation between $\mathrm{Cr}$ and $\mathrm{Co}$ in all the pepper samples investigated.

\section{CONClusion}

The levels of $\mathrm{Cd}, \mathrm{Fe}, \mathrm{Pb}, \mathrm{Zn}, \mathrm{Co}$, and $\mathrm{Cr}$ in the groups of pepper sold in major markets in Osogbo town have been successfully determined using AAS. For all the peppers investigated, the values of all heavy metals investigated when compared with the maximum permissible limit set by FAO/WHO (2012) for leafy vegetables and fruiting vegetables are below the FAO/WHO limits. This study has shown that samples of pepper sold in selected markets in Osogbo town are not contaminated with the investigated heavy metals $(\mathrm{Cd}, \mathrm{Fe}, \mathrm{Pb}, \mathrm{Zn}, \mathrm{Co}$, and $\mathrm{Cr}$ ), though the influx of environmental pollution basically from vehicle exhaust and other gaseous air pollutant could cause an increase in their values when compared with the samples from the market free from vehicular exhaust. It is therefore recommended that the levels of heavy metals in the peppers should be continuously monitored to check on their levels. Also, the sources of heavy metals in soils like inorganic fertilizers, pesticides and acaricides must be controlled when using in growing peppers. Fertilizers, pesticides and acaricides are known to be the sources of some of the heavy metals like lead, zinc and cadmium.

\section{REFERENCES}

[1] Abdalla, M. A. A. (2014). Heavy metals uptake by Chilli plants (Capsicum annuиml.) planted in rice husk char and coco peat media. M.Sc. published thesis, UniversitiSains Malaysia, Pp 110.

[2] Ahmed, B. A. and Bouhadjera, K. (2010).Assessment of metals accumulated in Durum wheat (Triticum durum Desf.), pepper (Capsicum annuит) and agricultural soils. African Journal of Agricultural Research, 5(20): 2795-2800.

[3] ATSDR (2015).Substance priority list, Agency for toxic substances and disease registry.(ATSDR), US Department of Health and Human Services.

[4] Barakat, M. A. (2011). New trends in removing heavy metals from industrial waste water Arabian Journal of Chemistry, 4: 361-377.

[5] Cao, H.; Chen, J.; Zhang, J.; Zhang, H.; Qiao, L. and Men, Y. (2010).Heavy metals in rice and garden vegetables and their potential health risks to inhabitants in the vicinity of an industrial zone in Jiangsu, China. Journal of Environmental Science, 22: 1792-1799. 
[6] Colak, H, Soylak, M and Turkuglu, O (2005): Determination of trace metals contents of various herbal and fruit teas produced and marketed from Turkey. Trace Elem. Electrolytes, 22: 192-195.

[7] Darko, B;Atim, I and Voegborlo, R.B (2014): Detection of Heavy metal content of pepper and seasonings on the Ghanaian markets. African Journal of Food Science. 8 (1): 14-19.

[8] Environmental health criteria for cadmium; International Programme on Chemical Safety (IPCS); 1992)

[9] FAO (2008). The state of food and Agriculture. BIOFUELS: prospects, risk and opportunities

[10] FAO/WHO (2012).Working document for information and use in discussions related to contaminants and toxins in the GSCTFF. Joint FAO/WHO food standards Programme. CODEX committee on contaminants in foods, Sixth Session, Maastricht, The Netherlands.

[11] Gaya, U. I. and Ikechukwu, S. A. (2016). Heavy metal contamination of selected spices obtained from Nigeria. Journal of Applied Science and Environmental Management, 20(3): 681-688.

[12] International Programme on Chemical Safety (IPCS) (1992). Environmental Health Criteria 134

[13] Järup, L. (2003). Hazards of heavy metal contamination. British Medical Bulletin,68: 167- 182.

[14] Jones, J.B. and Case, V.W. (1990).Sampling, handling and analyzing plant tissue sample. Soil testing and plant analysis, SSSA Inc. Madison. Southern Cooperative Series Bulletin \#368: 11-21.

[15] Kimani, M.Z, Mohiuddin, S, Naz, F, Naqvi, I.I and Zahir, E (2011); Detection of heavy metals in pepper. J. Basic and Applied Science. 7(2): 89-95

[16] Luke, J. A (1997): Effect of Fluoride on the physiology of the pineal gland. A dissertation submitted to the school of Biological Sciences, University of Survey. 1(9); 51-53.

[17] Makanjuola, O. M. and Osinfade, B. G. (2016).Evaluation of heavy metals in peppers sold along PapaAbeokuta highways, Ogun State, Southwest, Nigeria International Journal of Research Studies in Biosciences (IJRSB), 4(10): 1-3.

[18] Mandal, B. K. and Suzuki, K. T. (2002). Arsenic round the world: a review. Talanta, 58: 201-235.

[19] Michael, H (2010).Encyclopedia of Health National Council for Science and the Environment. Washington D.C. Article 150368:1.

[20] Olaniyi, J. O. and Ojetayo, A. E. (2010).The effect of organomineral and inorganic fertilizers on the growth, fruit yield and quality of pepper (capsicum frutescence). Animal \& plant Sci.: 8 (3): 1070 - 1076

[21] Osakwe, S.A; Okolie, L. P. (2015). Physicochemical Characteristics and Heavy Metals Contents in Soils and Cassava Plants from Farmlands along A Major Highway in Delta State, Nigeria. Journal of Applied Science and Environmental Management, 19(4): 695-704.

[22] Tijani, N. M. and Onodera, S. (2009). Hydrogeochemical Assessment of Metals Contamination in an Urban Drainage System: A Case Study of Osogbo Township, SW-Nigeria. Journal of Water Resource and Protection, 3: 164-173.

[23] Wierzbicka, M (1999): The effect of load on the cell cycle in the root meristem of Allium copa L. Protoplasm. 207: 186-194

Citation: ORISADARE Oluseyi Adewale, et.al, "Assessment of Heavy Metals in Peppers Sold in Major Markets in Osogbo, Osun State, Southwest, Nigeria”, International Journal of Advanced Research in Chemical Science, 7(9), pp. 1-8. DOI: https:// doi.org/10.20431/2349-0403.0709001

Copyright: () 2020 Authors, this is an open-access article distributed under the terms of the Creative Commons Attribution License, which permits unrestricted use, distribution, and reproduction in any medium, provided the original author and source are credited. 